\title{
MAUROLICUS STEHMANNI PARIN \& KOBYLIANSKY, 1993 (STERNOPTYCHIDAE): LENGTH OF FIRST MATURATION, AND SPAWNING SEASONS IN THE SOUTH-SOUTHEAST BRAZILIAN REGION
}

\author{
Eduardo Machado de Almeida ${ }^{1}$ and Carmen Lucia del Bianco Rossi-Wongtschowski ${ }^{2}$ \\ ${ }^{1}$ Centro de Pesquisa e Gestão de Recursos Pesqueiros do Nordeste do \\ Instituto Chico Mendes de Conservação da Biodversidade \\ (Rua Samuel Hardman s/n, 55578-000 Tamandaré, PE, Brasil) \\ ${ }^{2}$ Instituto Oceanográfico da Universidade de São Paulo \\ (Praça do Oceanográfico, 191, 05508-120 São Paulo, SP, Brasil)
}

\begin{abstract}
A B S T R A C T
Maurolicus stehmanni (Sternoptychidae) is a mesopelagic species of fish inhabiting the outer continental shelf and slope of the south-southeastern Brazilian (ZEE), where it presents a considerable biomass and is an important component of the trophic chain, as a forage species. On the basis of catches made with a mid-water-trawl net in 1996 and 1997, as part of the REVIZEE program, samples from 38 hauls were analyzed as regards the length structure of the population, the average length of the first maturation and the spawning seasons of the species. The analysis of histological cross-sections of the ovaries made it possible to describe the oocytic development and assess the macroscopic criteria used to classify the ovary maturation. Results showed that the average length of the first maturation occurs at $32 \mathrm{~mm}$ (standard length), females spawn all year round throughout the area studied and the oocytic development is asynchronous.
\end{abstract}

\section{RESUMO}

Maurolicus stehmanni (Sternoptychidae) é um pequeno peixe mesopelágico que habita a plataforma continental e o talude da região entre Cabo de São Tomé (22 S) e Chuí (34 S). No Atlântico Oeste, apresenta biomassa de cerca de 1 ton e é um importante componente da dieta de peixes pelágicos e demersais com valor comercial. A partir de capturas realizadas com rede de meia água, em $1996 \mathrm{e}$ 1997, dentro do programa (REVIZEE), exemplares provenientes de 38 lances de pesca foram analisados em relação à estrutura da população em comprimento e aos estágios de maturação macroscópica das gônadas, dados que, associados a dados biométricos, permitiram estimar o tamanho médio da $1^{\mathrm{a}}$ maturação e épocas de desova da espécie. Foram realizados, ainda, cortes histológicos de ovários e testículos com vistas a aferir a avaliação macroscópica e analisar o desenvolvimento ovocitário da espécie. Os resultados indicam que o tamanho médio da $1^{\mathrm{a}}$ maturação é de $32 \mathrm{~mm}$ de comprimento padrão, as fêmeas desovam o ano todo e que a desova ocorre ao longo de toda a borda da plataforma continental sudeste-sul do Brasil. O desenvolvimento ovocitário é assincrônico, mostrando que $M$. stehmanni apresenta desova parcelada.

Descriptors: Maurolicus stehmanni, Mesopelagic fish, Spawning sites, Reproduction, Length of first maturation, Ovary development.

Descritores: Maurolicus stehmanni, Peixes mesopágicos, Reprodução, Comprimento da primeira maturação, Desenvolvimento ovariano.

\section{INTRODUCTION}

Maurolicus stehmanni Parin \& Kobyliansky, 1993 (Sternoptychidae) is found in the Western Atlantic between $23^{\circ} \mathrm{S}$ and $40^{\circ} \mathrm{S}$. It is of great importance to the pelagic and demersal ecosystems of the outer shelf and slope of the south-southeastern Brazilian region since it constitutes an important item in the diet of large pelagic and demersal fishes (ZAVALA-CAMIN, 1981; ANKEBRANDT, 1985; HAIMOVICI et al., 1994; MUTO et al., 2005). During

$\overline{\text { Cont. no. } 873}$ do Inst. oceanogr. da Usp. hydroacoustic prospecting cruises undertaken between August 1996 and December 1997 in the southsoutheastern Brazilian region, the average biomass of this species was estimated at 1 million tons (GREIG, 2000; MADUREIRA et al., 2005).

Species of the Maurolicus genus have a short life span, rapid growth and great fecundity and, thus, alterations in the environment, whether in physical or biological terms, may lead to rapid changes in these biological parameters (SALVANES; STOCKLEY, 1996).

Since M. stehmanni presents a considerable biomass and is an important element of the food web 
in the region, its stock management should be preceded (and maintained) by biological studies which will allow its monitoring. To date, only age and growth parameters are available (BELLUCCO et al., 2004). The aim of the present study is to contribute with new biological information about the species, regarding its population composition, in terms of proportions of males and females, and young and adults, average size of first maturation, spawning seasons, oocytic development and species spawning phases.

\section{Material and Methods}

The samples used in this study were caught with a mid-water-trawl net during three cruises using acoustic prospections for pelagic resources of the REVIZEE program, undertaken with the $\mathrm{R} / \mathrm{V}$ Atlântico Sul. Details on the collection and characteristics of the study area are to be found in Almeida (2001), Figueiredo et al. (2002) and Madureira and Rossi-Wongtschowski (2005). Three cruises (I, II , III) were undertaken during the winter of 1996 (July, August, September), the autumn of 1997 (April, May) and the spring of 1997 (November, December), respectively, covering the whole area between the Cape of São Tomé $\left(22^{\circ} \mathrm{S}\right)$ and the Arroio Chuí $\left(34^{\circ} \mathrm{S}\right)$, between depths of 100 to $1500 \mathrm{~m}$ (Fig. 1). M. stehmanni was collected in 42 catches (Fig. 2).
Once on board 150 specimens were separated randomly from each catch and then frozen and sent ashore for analysis.

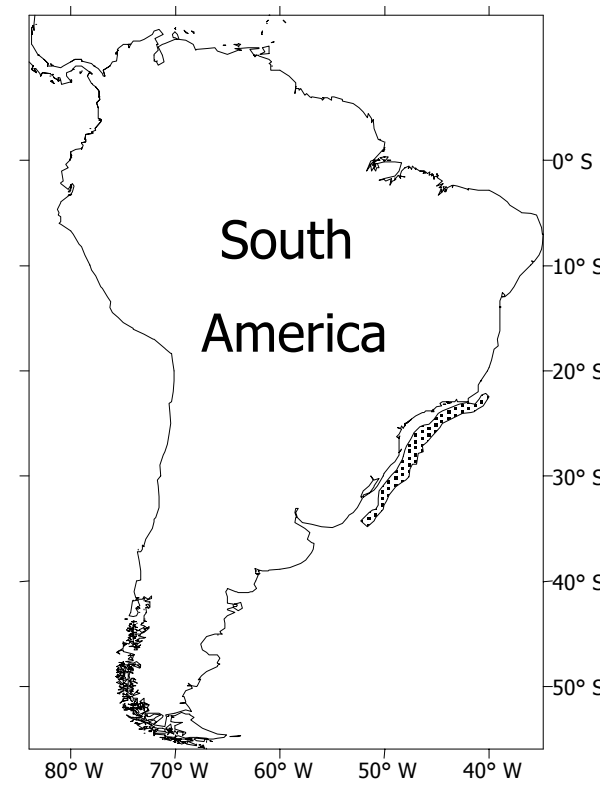

Fig. 1. Study area (shaded)

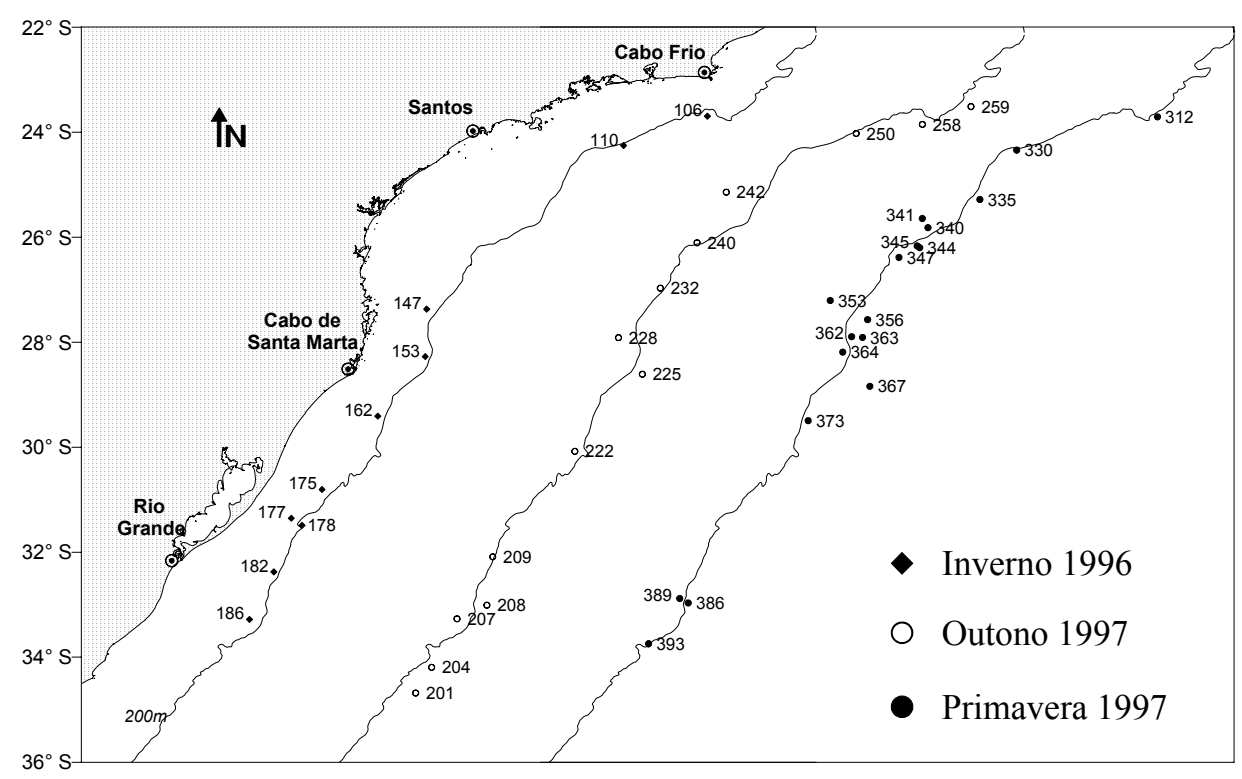

Fig. 2. Maurolicus stehmanni: distribution of fishing catches by species and season of the year. 
At the laboratory, the measurements of standard length (Ls), in $\mathrm{mm}$, and of total weight $(\mathrm{Wt})$ in $\mathrm{g}$, were obtained, sixty of the specimens were identified by sex and the maturity of their gonads classified under the stereomicroscope in accordance with the maturity scale proposed by Vazzoler (1996), which used five stages, namely, immature (A), undergoing maturation $(B)$, mature $(C)$, spawned (D) and at rest $(\mathrm{E})$. The gonads were removed, weighted $\left(\mathrm{W}_{0}\right)$ and maintained in $4 \%$ formaline for 24 hours, then transferred to $70 \%$ alcohol.

Samplings from two other cruises (IV, V), undertaken using the same methodology as the previous ones, though covering a more restricted area, near Itajaí (MADUREIRA et al., 2005), were used for histological analysis of the ovaries. Fish from each of the catches had their length measurements taken and their ovaries were fixed in $4 \%$ formaline, as soon as they were taken out of the net, in order to preserve their cells and ovarian structures. Before being fixed, these gonads were classified macroscopically and later received the same treatment for the mounting of permanent preparations as that described before.

\section{Analyses Undertaken \\ Population Structure}

The proportion of males and females per catch was calculated, as well as their relationship to the length of specimens, in accordance with the method described in Vazzoler (1996). The hypothesis of the proportion of males to females being $1: 1$ $(\mathrm{p}=0.05)$ was tested by the $\mathrm{X}$-squared test $(\mathrm{ZAR}$, 1996).

Juveniles and adults proportion was analyzed by season, juveniles being understood as fish whose gonads were immature (A) and as adults, all those classified in the other stages (B, C, D and E).

\section{Average Length of the First Maturation}

According to Vazzoler (1996), this is the length at which $50 \%$ of the fish of a particular species attain gonadal maturity $\left(\mathrm{L}_{50}\right)$ for the first time. This length was estimated on the basis of the adult individuals proportion, by class of standard length, the logistic curve being adjusted to the points obtained using the method proposed by King (1995). The calculation of the $\mathrm{L}_{50}$ was performed for males and females together, due to the difficulty in identifying sex of the immature fish macroscopically.

For the purpose of comparing data obtained in this study with information available in the literature, both the minimum standard length of maturation $\left(\mathrm{L}_{\min }\right)$ and the maximum standard length of maturation $\left(\mathrm{L}_{\max }\right)$ were calculated separately for males and females, representing the minimum and maximum sizes of the fish with ripe gonads, namely, those in stage C (DALPADADO; GJØSÆTER, 1987; YOUNG et al., 1987; PROSCH, 1991; RASMUSSEN; GISKE, 1994).

In order to evaluate the influence of environmental factors on the average size of the first maturation and in the theoretic maximum length, the relationship $\mathrm{L}_{50} / \mathrm{L} \infty$, proposed by Longhurst and Pauly (1987) was calculated for the hole set of data and for each season. This calculation was also peformed using the $\mathrm{L}_{\min }$, thus permitting comparisons with data from the related literature.

\section{Spawning Seasons}

The following items were analyzed for the purpose of verifying the existence of the spawning seasons of M. stehmanni in the study area:

- Frequency of the gonadal maturity stages by cruise, for all fishes (males and females in their respective groups), which, according to West (1990), indicates spawning through the presence of mature fish.

-Gonadosomatic relationship (GSR), which expresses the ratio, as a percentage, of the gonad weight to the fish weight (total or body weight). Its variation, over time, indicates the period of greatest reproductive activity, so as this ratio tends to increase during ovarian development (WOOTTON, 1990; KING, 1995).

The average value of the GSR was calculated on the basis of the expressions below, presented by Vazzoler (1996), for adult females, taking into account the seasons of the respective catches and the stages of ovarian maturity:

$\mathrm{GSR}_{1}=100 * \mathrm{~W}_{\mathrm{o}} / \mathrm{W}_{\mathrm{t}}$ and $\mathrm{GSR}_{2}=100 * \mathrm{~W}_{\mathrm{o}} / \mathrm{W}_{\mathrm{c}}$ where,

$\mathbf{W}_{\mathbf{c}}=\mathbf{W}_{\mathbf{t}}-\mathbf{W}_{\mathbf{0}}=$ body weight

-Delta $\mathbf{K}(\Delta \mathbf{K})$. This index reveals, in relative terms, how much of the energy obtained by the fish is being carried to gonadal development, being an indicator of the reproductive period (VAZZOLER, 1996). One is here dealing with the subtraction of the condition factor $(\mathrm{K})$ from the factor of the body condition ( $\mathrm{K}^{\prime}$ ) calculated as the body weight minus the weight of the gonad, and was calculated only for adult females, by stage of maturity, and by season, using the formulae:

$\Delta \mathrm{K}=\mathrm{K}-\mathrm{K}^{\prime}$ where $\mathrm{K}=\mathrm{W}_{\mathrm{t}} / \mathrm{Ls}^{\mathrm{b}}$ and $\mathrm{K}^{\prime}=\mathrm{W}_{\mathrm{c}} / \mathrm{Ls}^{\mathrm{b}} * 10^{4}$

$\mathrm{b}$, being the linear regression of the logarithmic data obtained from the length-weight relation. Differences 
between males and females slopes were examined using Student's $t$-test (ZAR, 1996).

\section{Histology of the Gonads}

Permanent preparations of ovaries and testicles cross-sections were mounted, in accordance with Vazzoler (1996) methodology, to evaluate the accuracy of the macroscopic classification of the used gonadal maturity stages. In this case, the number of gonads examined varied, seeking to obtain the preparation of at least three gonads of each maturity stage found in fish captured in each catch. The analysis of the gonad histological cross sections were also used in order to describe the oocytic development of the species.

\section{Results AND Discussion}

The total sampling consisted of 6132 specimens of $M$. stehmanni, with standard lengths between 12 and $50 \mathrm{~mm}$.

\section{Composition of the Population}

Sexual proportions of specimens captured in catches of cruises I to III and the result of the Xsquared test are displayed in Table 1 . Only 8 catches out of 42 , presented a ratio significantly different from $1: 1(\mathrm{p}=0.05)$, and no space-time pattern was found in the distribution of males and females.

Table 1. Maurolicus stehmanni: numerical values, percentage of males and females and values of $\mathrm{X}$-squared test, by fishing catch and season of the year. The asterisks $\left({ }^{*}\right)$ indicate those captures with sexual proportions significantly different from $1: 1(\mathrm{p}=$ $0.05)$

\begin{tabular}{|c|c|c|c|c|c|c|c|c|c|}
\hline & \multirow{2}{*}{ Catch } & \multicolumn{2}{|c|}{ Numbers } & \multicolumn{2}{|c|}{ Percentage $(\%)$} & \multirow{2}{*}{$\frac{\mathrm{X}^{2}}{\text { Value }}$} & \multirow{2}{*}{$\begin{array}{l}\mathrm{F} / \mathrm{M} \\
\text { Ratio }\end{array}$} & \multicolumn{2}{|c|}{ Ls (mm) } \\
\hline & & Males & Females & Males & Females & & & Min & Max \\
\hline \multirow{7}{*}{$\begin{array}{c}\mathbf{W} \\
\mathbf{i} \\
\mathbf{n} \\
\mathbf{t} \\
\mathbf{e} \\
\mathbf{r}\end{array}$} & 106 & 78 & 63 & 55,3 & 44,7 & 1,60 & & 33 & 42 \\
\hline & 110 & 76 & 77 & 49,7 & 50,3 & 0,01 & & 33 & 44 \\
\hline & 147 & 22 & 9 & 71,0 & 29,0 & $5,45 *$ & 0,41 & 24 & 40 \\
\hline & 153 & 73 & 71 & 50,7 & 49,3 & 0,03 & & 33 & 48 \\
\hline & 162 & 0 & 2 & 0,0 & 100,0 & & & 23 & 35 \\
\hline & 178 & 39 & 44 & 47,0 & 53,0 & 0,30 & & 24 & 44 \\
\hline & 186 & 4 & 2 & 66,7 & 33,3 & 0,67 & & 28 & 42 \\
\hline \multirow{13}{*}{$\begin{array}{c}\mathbf{A} \\
\mathbf{u} \\
\mathbf{t} \\
\mathbf{u} \\
\mathbf{m} \\
\mathbf{n}\end{array}$} & 259 & 17 & 33 & 34,0 & 66,0 & $5,12 *$ & 1,94 & 38 & 49 \\
\hline & 258 & 23 & 21 & 52,3 & 47,7 & 0,09 & & 30 & 49 \\
\hline & 250 & 33 & 15 & 68,8 & 31,3 & $6,75^{*}$ & 0,45 & 31 & 45 \\
\hline & 242 & 2 & 7 & 22,2 & 77,8 & 2,78 & & 29 & 38 \\
\hline & 240 & 24 & 14 & 63,2 & 36,8 & 2,63 & & 34 & 51 \\
\hline & 232 & 10 & 19 & 34,5 & 65,5 & 2,79 & & 34 & 47 \\
\hline & 228 & 18 & 7 & 72,0 & 28,0 & $4,84 *$ & 0,39 & 24 & 30 \\
\hline & 225 & 28 & 22 & 56,0 & 44,0 & 0,72 & & 30 & 45 \\
\hline & 222 & 13 & 13 & 50,0 & 50,0 & 0,00 & & 29 & 39 \\
\hline & 209 & 29 & 21 & 58,0 & 42,0 & 1,28 & & 30 & 40 \\
\hline & 207 & 8 & 4 & 66,7 & 33,3 & 1,33 & & 30 & 39 \\
\hline & 203 & 23 & 14 & 62,2 & 37,8 & 2,19 & & 30 & 39 \\
\hline & 201 & 7 & 6 & 53,8 & 46,2 & 0,08 & & 31 & 39 \\
\hline \multirow{18}{*}{$\begin{array}{l}\mathbf{S} \\
\mathbf{p} \\
\mathbf{r} \\
\mathbf{i} \\
\mathbf{n} \\
\mathbf{g}\end{array}$} & 312 & 11 & 18 & 37,9 & 62,1 & 1,69 & & 30 & 40 \\
\hline & 330 & 13 & 10 & 56,5 & 43,5 & 0,39 & & 31 & 41 \\
\hline & 335 & 29 & 28 & 50,9 & 49,1 & 0,02 & & 37 & 46 \\
\hline & 340 & 7 & 49 & 12,5 & 87,5 & $31,50 *$ & 7,00 & 27 & 46 \\
\hline & 341 & 14 & 7 & 66,7 & 33,3 & 2,33 & & 33 & 44 \\
\hline & 344 & 24 & 16 & 60,0 & 40,0 & 1,60 & & 30 & 46 \\
\hline & 345 & 30 & 29 & 50,8 & 49,2 & 0,02 & & 37 & 47 \\
\hline & 347 & 26 & 33 & 44,1 & 55,9 & 0,83 & & 35 & 45 \\
\hline & 353 & 26 & 28 & 48,1 & 51,9 & 0,07 & & 29 & 37 \\
\hline & 356 & 11 & 11 & 50,0 & 50,0 & 0,00 & & 28 & 47 \\
\hline & 362 & 5 & 9 & 35,7 & 64,3 & 1,14 & & 25 & 40 \\
\hline & 363 & 4 & 3 & 57,1 & 42,9 & 0,14 & & 27 & 43 \\
\hline & 364 & 6 & 4 & 60,0 & 40,0 & 0,40 & & 28 & 35 \\
\hline & 367 & 3 & 0 & 100,0 & 0,0 & & & 28 & 48 \\
\hline & 373 & 9 & 25 & 26,5 & 73,5 & $7,53 *$ & 2,78 & 24 & 40 \\
\hline & 386 & 18 & 33 & 35,3 & 64,7 & $4,41 *$ & 1,83 & 40 & 46 \\
\hline & 389 & 1 & 17 & 5,6 & 94,4 & $14,22 *$ & 17,00 & 31 & 38 \\
\hline & 393 & 3 & 4 & 42,9 & 57,1 & 0,14 & & 34 & 41 \\
\hline
\end{tabular}


Differently from the result of this study, Rasmussen and Giske (1994) in Norway; Prosch (1991) in South Africa; Dalpadado and Gjøsæter (1987) in the Red Sea; Young et al. (1987) in Tasmania and Clarke (1982) in Australia, studying species of the genus Maurolicus, reported a significantly larger number of females than males. Prosch (op. cit.) found a 1.2:1 female to male ratio and suggested that this difference might be due to sexual stratification, in view of the fact that females undertook vertical nocturnal migration closer to the surface in the summer. Young et al. (op. cit.) reported several fishing catches containing only males or females, suggesting the existence of a spatial segregation as between shoals of males and females. No such facts were observed for Maurolicus stehmanni in the south-southeastern region of Brazil.

As for the sexual proportion by standard length class (Ls), due to the difficulty in sex identification of the immature fish, the number of small-sized specimens was small; however, for the adult fish, an oscillation around $50 \%$ was observed, with no clear and defined pattern below $48 \mathrm{~cm}$, above which point only females appeared (Fig. 3).

The observation that among the greater lengths only females appeared is corroborated by studies of Rasmussen and Giske (1994); Prosch (1991); Young et al. (1987); and Dalpadado and Gjøsæter (1987), for different species of Maurolicus. Rasmussen and Giske (op. cit.) attribute this fact to a higher mortality rate among males, which present different growth patterns from those of the females. Different growth patterns have been described by Bellucco et al. (2004), for males and females of $M$. stehmanni, in the same area where the present study was undertaken, revealing that females attain greater lengths and ages than the males.

The proportion of juveniles and adults, by seasons, is given in Figure 4, in which it may be seen that juveniles and adults occurred in all of the three periods, with minor variations. Results show that recruiting occurred in the three seasons, though with a greater incidence of juveniles in the spring and a minor one in the autumn.

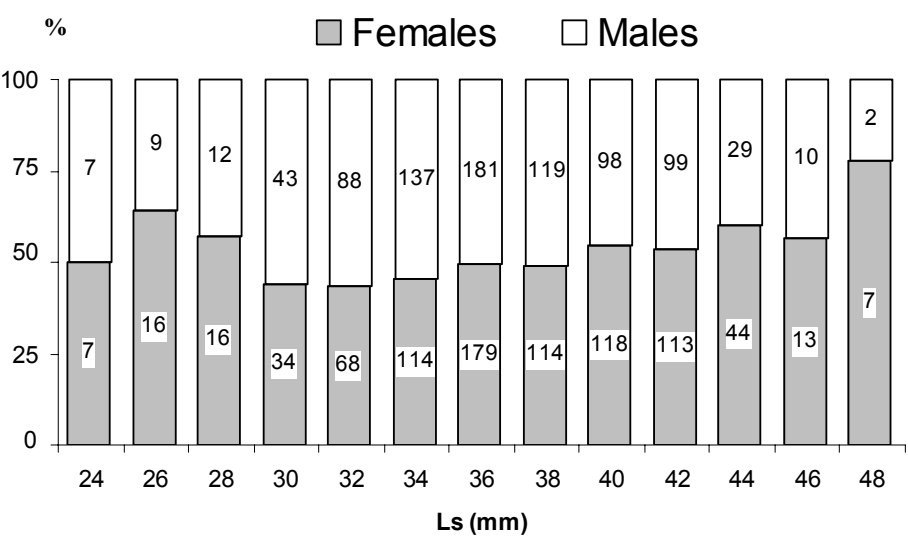

Fig. 3. Maurolicus stehmanni: proportion of males and females by standard length class (Ls). Numbers inside columns correspond to individuals analysed.

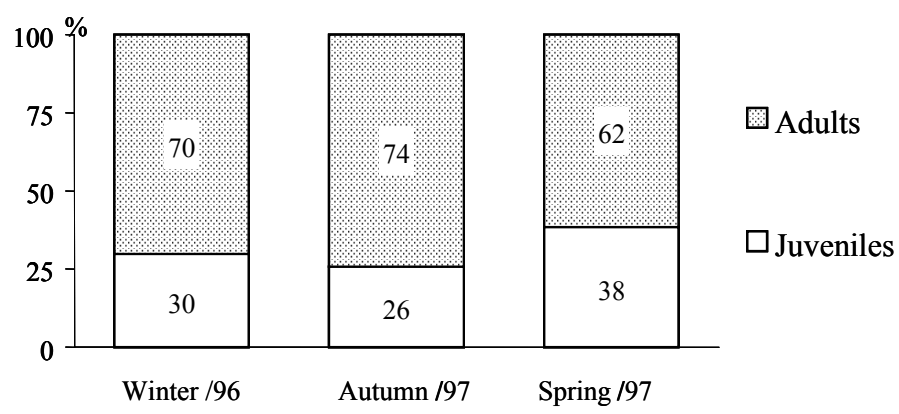

Fig. 4. Maurolicus stehmanni: proportion of juvenile and adult fish by season. Numbers inside columns correspond to individuals analysed. 


\section{Average Length of the First Gonadal Maturation}

The proportion of adult fish by standard length class and the estimate of $\mathrm{L}_{50}$ are given in Figure 5. The average size of the first gonadal maturation, namely, the size at which $50 \%$ of fish population presents gonadal maturity, was estimated at $32 \mathrm{~cm}$.

Due to the difficulty in identifying the sex of individual immature fish macroscopically, this parameter was calculated with data of males and females altogether, what did not permit comparisons with other studies that have mentioned differences between the maturation of males and females of various species of the genus (YOUNG et al., 1987; DALPADADO; GJØSÆTER, 1987; PROSCH, 1991 and RASMUSSEN; GISKE, 1994). Nevertless, different growth rates between males and females of Maurolicus stehmanni were found by Bellucco et al. (2004), that showed females attaining greater lengths than males.

The minimum $\left(\mathrm{L}_{\min }\right)$ and maximum $\left(\mathrm{L}_{\max }\right)$ maturation sizes obtained for males and females of $M$. stehmanni, as well as the results of other studies undertaken with related species, may be seen in Table 2 .

According to the results obtained it was found that males of M. stehmanni present such sizes at shorter lengths than those of females, corroborating other studies undertaken on the genus (YOUNG et al., 1987; DALPADADO; GJØSÆTER, 1987; PROSCH, 1991; RASMUSSEN; GISKE, 1994).

Stearns and Crandall (1984) and Wootton (1990) emphasize that, within one and the same species, the age and/or length of maturation may vary and that this plasticity is genetically determined and molded by environmental variables. Such facts result in different growth and mortality rates, leading to distinct ages (and lengths) of maturation.

Vazzoler (1996) discusses the concept of "critical minimum size", which corresponds to the size at which the critical reproductive processes begin and suggests that species with a short life cycle and small L $\infty$ (r-strategists), as is the case with M. stehmanni, attain mature gonadal stages earlier than those species with longer life-cycles and greater L $\infty$ (k-strategists). Longhurst and Pauly (1987) present the hypothesis that the theoretical maximum size $(\mathrm{L} \infty)$ and the first maturation $\left(\mathrm{L}_{50}\right)$ average length is determined mainly by the interaction between the supply of and demand for $\mathrm{O}_{2}$ (that is to say, the intake and expenditure of energy), and that this relationship is limited by the area of the gills, which guarantee the supply of $\mathrm{O}_{2}$ and do not grow in the same proportion as the volume of the body, responsible for the $\mathrm{O}_{2}$ demand. According to those authors (op. cit.), the gonads maturation must occur while there is an "excess" in the supply of energy and that the total metabolism (active metabolism + metabolism of maintenance) should be 1.4 times greater than the metabolism of maintenance. Thus, within one and the same taxonomic group, the relation $\mathrm{L}_{50} / \mathrm{L} \infty$ will remain constant and although environmental alterations may lead to variations in both the $\mathrm{L}_{50}$ and the $\mathrm{L} \infty$, they will not affect the relationship between these parameters. Finally, those authors showed that this relationship varies between 0.4 and 0.9 and that there is a tendency for these values to be smaller in larger fish and greater in smaller fish. In the light of Belluco et al. (2004) estimate for M. stehmanni's L $\infty$ of $53 \mathrm{~mm}$, the result of the relationship $\mathrm{L}_{50} / \mathrm{L} \infty$ would be 0.6 .

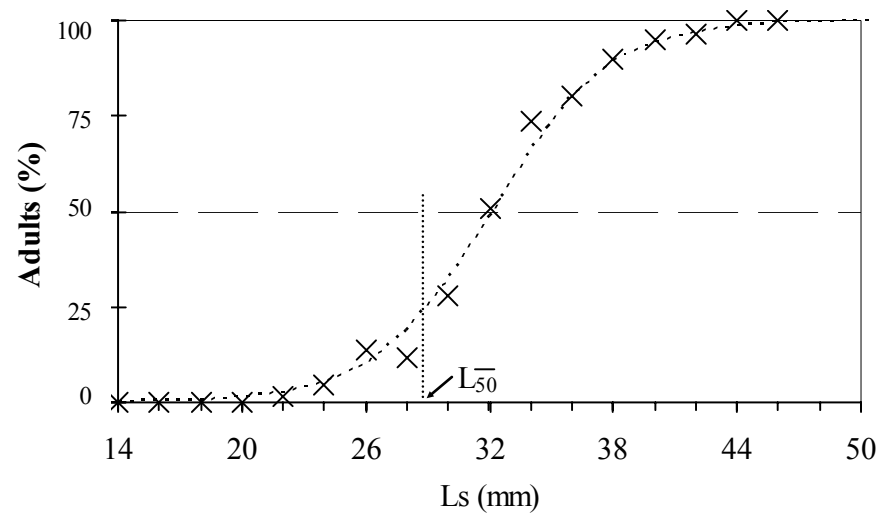

Fig. 5. Maurolicus stehmanni: percentage of adult individuals by standard length class (Ls). X: values obtained. $\left(\mathrm{L}_{50}\right)$ : average length of the first gonadal maturation. The graph has been adjusted in acordance with King`s (1995). 
Table 2. Minimum ( $\left.\mathrm{L}_{\min }\right)$ and maximum lengths $\left(\mathrm{L}_{\max }\right)$ of gonadal maturation; maximum sizes observed ( $\left.\mathrm{Ls}_{\max }\right)$ and relation between the minimum size of gonadal maturation and the maximum size obtained $\left(\mathrm{L}_{\min } / \mathrm{Ls}_{\max }\right)$ in this study for Maurolicus stehmanni and, by various authors, for other species of the genus Maurolicus.

\begin{tabular}{|c|c|c|c|c|c|c|c|}
\hline \multirow[b]{2}{*}{ Reference } & \multirow[b]{2}{*}{ Area } & \multicolumn{2}{|c|}{$\begin{array}{l}\mathbf{L}_{\min } \\
(\mathbf{m m})\end{array}$} & \multicolumn{2}{|c|}{$\begin{array}{c}\mathbf{L}_{\max } \\
(\mathbf{m m})\end{array}$} & \multirow[t]{2}{*}{$\begin{array}{l}\mathbf{L s} s_{\max } \\
(\mathbf{m m})\end{array}$} & \multirow[t]{2}{*}{$\begin{array}{r}\mathbf{L}_{\text {min }} \\
\mathbf{L} \mathbf{s}_{\text {max }}\end{array}$} \\
\hline & & Females & Males & Females & Males & & \\
\hline $\begin{array}{l}\text { This study } \\
\text { M. stehmanni }\end{array}$ & $\left(22\right.$ to $\left.35^{\circ} \mathrm{S}\right)$ & 24 & 23 & 51 & 48 & 52 & 0.46 \\
\hline Yuuki (1982) & $\begin{array}{c}\text { Japan } \\
\left(35 \text { to } 39^{\circ} \mathrm{S}\right)\end{array}$ & 40 & - & 56 & - & 56 & 0.71 \\
\hline $\begin{array}{c}\text { Young et al } \\
(1987)\end{array}$ & $\begin{array}{l}\text { Tasmania } \\
\left(42^{\circ} \mathrm{S}\right)\end{array}$ & 38 & 34 & 53 & 46 & 54 & 0.70 \\
\hline $\begin{array}{c}\text { Dalpadado and } \\
\text { Gjosaeter (1987) }\end{array}$ & $\begin{array}{c}\text { Southeast } \\
\text { Australia } \\
\left.\text { (33 to } 43^{\circ} \mathrm{S}\right)\end{array}$ & 20 & 19 & 40 & 34 & 40 & 0.50 \\
\hline Prosch (1991) & $\begin{array}{l}\text { South Africa } \\
\left(31 \text { to } 35^{\circ} \mathrm{S}\right)\end{array}$ & 26 & 24 & 53 & - & 53 & 0.49 \\
\hline $\begin{array}{c}\text { Rasmunsen and } \\
\text { Giske (1994) }\end{array}$ & $\begin{array}{l}\text { Norway } \\
\left(60^{\circ} \mathrm{N}\right)\end{array}$ & 25 & - & 59 & 48 & 59 & 0.42 \\
\hline
\end{tabular}

For the purpose of testing Longhurst and Pauly (1987) hypothesis described before, and without literature information for $\mathrm{L}_{50}$ or $\mathrm{L} \infty$ for the Maurolicus genus, but making use of the data on $\mathrm{L}_{\min }$, and assuming that $\mathrm{L}_{\max }$ approximates to $\mathrm{L} \infty$, the ratio between the $\mathrm{L}_{\min }$ of females and the maximum size Maurolicus genus species were calculated and are given in Table 2. The values obtained were about 0.5 , with exception of YOUNG et al. (1987) and YUUKI (1982) studies, the values obtained were 0.70 and 0.71 , respectively.

As compared with related species of South Africa and Norway, M. stehmanni matures at a closely similar minimum size, though smaller than that occurring off Japan and Tasmania waters. These differences cannot be related to latitude, but rather to ecological characteristics of each ecosystem, whether physical (hydrological structure) or biological (growth, competition and predation), which may lead to alterations in the population parameters such as size of maturation, growth rate and mortality rate.

\section{Spawning Seasons}

The analysis of the maturity frequency stages revealed high values for immature individuals (A), those in the process of maturation (B) and mature (C), in all of the three seasons covered by the cruises
(Fig. 6). No fish which had already spawned (D) or in resting phase were observed by eye in the samples. In winter, the proportion of specimens in the process of maturation was $46 \%$ and of mature fish $24 \%$. In spring, $36 \%$ of the fish were in maturation and $25 \%$ were mature. In autumn, the relative value for fish in maturing stage was $28 \%$ and the percentage of mature specimens was the highest found, 47\%. West (1990) affirms that the estimation of the stages of gonadal development frequencies permits the analysis of the length of maturation, the spawning season and the duration of the reproductive period. On the other hand, Vazzoler (1996) says that the ovarian development is a continuous and cyclical process and that its subdivision into stages is artificial but that the proportion between these stages is important for the studies on first maturation length, the reproductive period and the area of reproduction.

Although there are no data available related to summer, the high percentage of individuals both mature and in the maturation process, and yet the presence of immature fish in all the seasons indicate that Maurolicus stehmanni spawns throughout the area and all year round.

The parameters of the regression between Ws "versus" Ls are presented in Figure 7. 


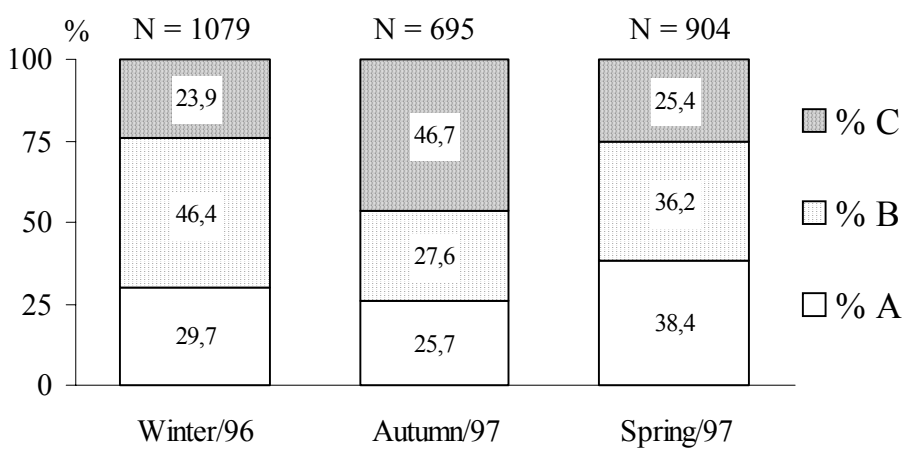

Fig. 6. Maurolicus stehmanni: percentage of the stages of gonadal maturity by season of the year. A - immature fish (juveniles); B - fish in the process of maturation (adults) and $\mathrm{C}$ - mature fish (adults). Numbers inside columns correspond to individuals analysed.

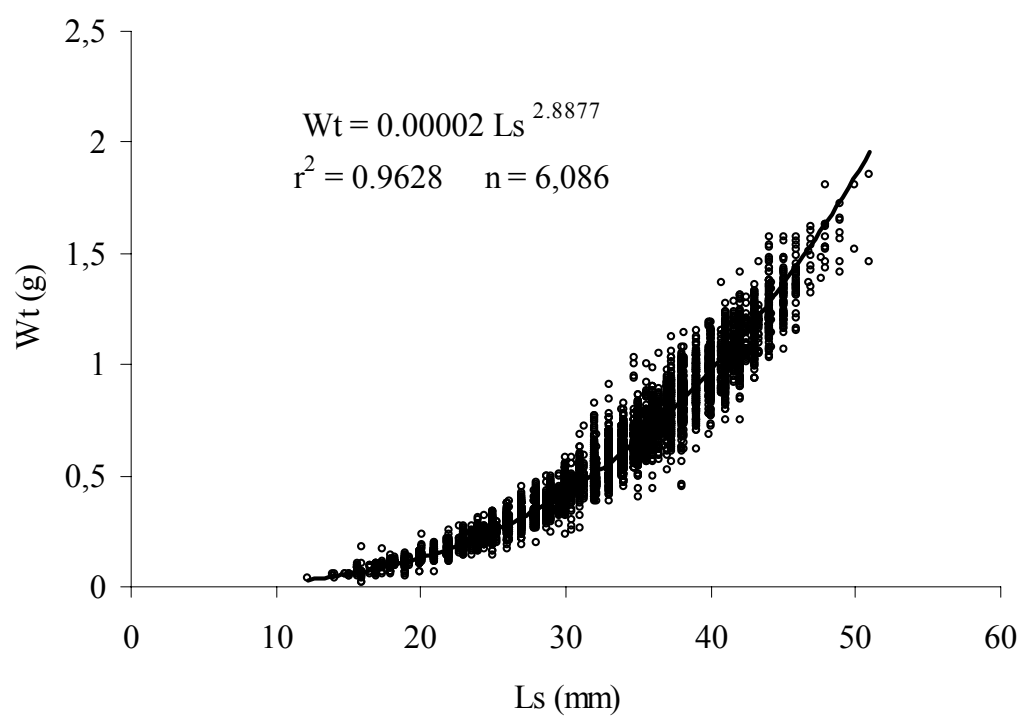

Fig. 7. Maurolicus stehmanni: length weight relationship.

The averages and the standard deviations of the Gonadosomatic Relationships $\left(\mathbf{G S R}_{\mathbf{1}}\right.$ and $\left.\mathbf{G S R}_{\mathbf{2}}\right)$ for the females are given in Table 3. The average values of these indices for the mature females $(\mathrm{C})$, in winter, were about $3.3 \%$ higher.

In spring and autumn the values approximated to 2.4. For the females in the maturation process (B), the lowest values, around 0.8 , were obtained in spring.

In the light of the above descriptions, the values of $\mathrm{GSR}_{1}$ and $\mathrm{GSR}_{2}$ were always higher for the "C" females, which means that the weight of the gonads and their value in relation to the body weight may be used as appropriate tools for the assessment of the gonadal maturation of the species.

Studies on the gonadosomatic relationship of the females of Maurolicus muelleri undertaken by Clarke (1982) and Young et al. (1987) in Australia, and by Rasmussen and Giske (1994) and Salvanes and Stockley (1996) in Norway, show that the highest values of $\mathrm{GSR}_{1}$ corresponded to more advanced stages of ovarian development, corroborating the estimates of the spawning seasons of the species. 
Table 3. Mean values and standard deviations of $\mathrm{GSR}_{1}$ and $\mathrm{GSR}_{2}$ of females in process of maturation (B) e mature (C) of Maurolicus stehmanni, for the three periods sampled.

\begin{tabular}{lccccc}
\hline \hline & & \multicolumn{2}{c}{ GSR $_{1}$} & \multicolumn{2}{c}{ GSR $_{2}$} \\
\hline \multirow{2}{*}{ Winter } & Mean & 1.923 & 3.229 & 1.976 & 3.364 \\
& s.d & 1.171 & 1.567 & 1.227 & 1.697 \\
& Mean & 1.239 & 2.391 & 1.261 & 2.463 \\
Autumn & s.d. & 0.810 & 1.123 & 0.835 & 1.191 \\
& Mean & 0.769 & 2.397 & 0.779 & 2.478 \\
Spring & s.d. & 0.590 & 1.410 & 0.603 & 1.498 \\
\hline
\end{tabular}

Values of $\mathrm{GSR}_{1}$ reported in the literature, as related to Maurolicus muelleri, were similar to those found in this study for M. stehmanni. For the former, Rasmussen and Giske (1994) in Norway, found a maximum value of $7 \%$, as well as discovered that specimens of less than $30 \mathrm{~mm}$ never attain values above 2\%. Further, Clark (1982) in Australia, presented a range for $\mathrm{GSR}_{1}$ values between 1.6 and $9.6 \%$, a maximum value similar to that obtained for $M$ stehmanni in the present study. Salvanes and Stockley (1996), analyzing specimens from areas of the open ocean and of Norwegian fjords in different localities, found average values of $\mathrm{GSR}_{1}$ between 1.21 and 5.26 $\%$ for $M$. muelleri, the highest averages being intimately related to the diameter of the oocyte, that is to say, the highest values of $\mathrm{GSR}_{1}$ occurred in females which presented more advanced stages of ovarian maturity. Young et al. (1987), in Tasmania, Australia, also for M. muelleri, found a direct relationship between $\mathrm{GSR}_{1}$ and ovarian development and, further, average values of this index, varying from 4 to $4.5 \%$, in the peak spawning seasons.

In the present study, the average values for $\mathrm{GSR}_{1}$ and $\mathrm{GSR}_{2}$, as much for the mature females (C) as for those in the process of maturation (B), were higher in winter, diminishing in the other periods. The occurrence of fish with high values of $\mathrm{GSR}_{1}$ (about $6 \%$ ) in the three seasons shows that M. stehmanni presented reproductive activity in all the seasons. Higher values of $\mathrm{GSR}_{1}, \mathrm{GSR}_{2}$ and delta $\mathrm{K}(\Delta \mathrm{K})$, for females in the process of maturation (B) and mature (C) in the winter and lower in spring (Fig. 7), suggest that there was a greater reproductive investment in winter, that is to say, a possible maturation peak.

It should be observed that the values of $\Delta \mathbf{K}$

(Fig. 8) were always greater for the $\mathrm{C}$ females than for the $\mathrm{B}$ ones, showing that the gonad weight given by this index is appropriate for the assessment of the $M$. stehmanni maturity.

Figure 8 presents the length/weight relationship for Maurolicus stehmanni. Since there was no significant difference between males and females slopes $(P>0.05)$ data were grouped and the parameters $a$ and $b$ of the equation were estimated for fish of both sexes altogether.

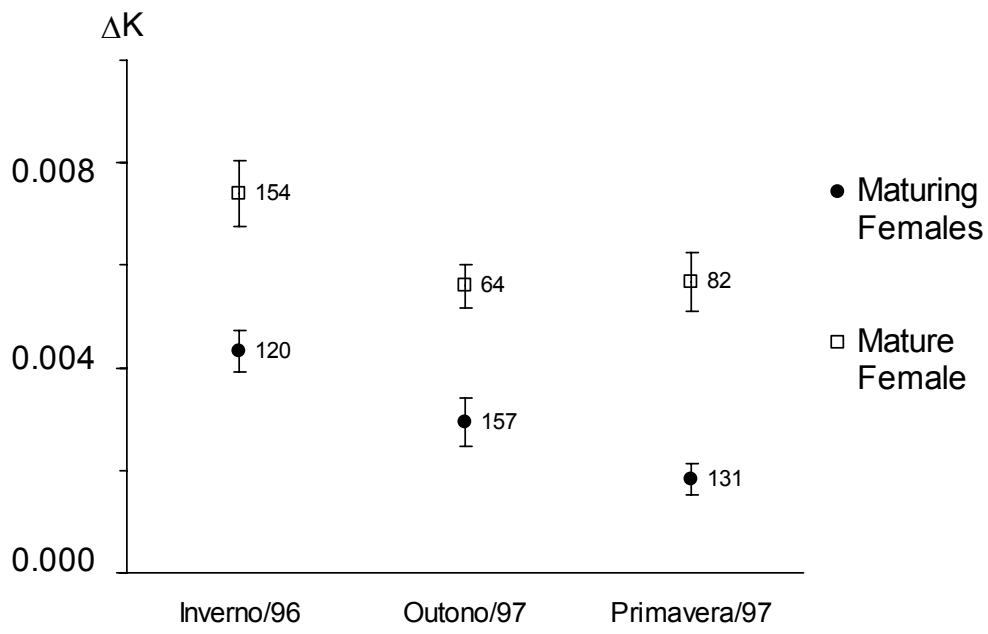

Fig. 8. Maurolicus stehmanni: average values of Delta $\mathrm{K}$ for females in maturation (B) and mature (C), by season of the year. The vertical bars represent the confidence intervals $(p=0.05)$, Numbers next to dots correspond to individuals analysed. 
Studies on the ichthyoplancton undertaken in the southern region (WEISS et al., 1988; BONECKER; HUBOLD, 1990) and in the southeastern region (RIBEIRO, 1996) of Brazil, in the same region as that of the present study, demonstrated the occurrence of eggs and larvae of M. stehmanni in all the seasons analyzed. Ribeiro (op. cit.) concluded that the species spawns all year round, with a spring/summer peak. In this study the highest values of $\mathrm{GSR}_{1}$ and $\Delta \mathrm{K}$, obtained for winter indicate that in this period the species presents maximum maturation, and that in it a spawning peak may have occurred.

Despite the fact that no hydrated ovaries were found, which would indicate imminent spawning, the results show that $M$. stehmanni presented reproductive activity in all the three seasons analyzed, thus corroborating the studies of Weiss et al. (op. cit.), Bonecker and Hubold (op. cit.) and Ribeiro (op. cit.), inspite the fact that it has not been possible to undertake summer catches, would not allow to affirm anything regarding reproductive activity in that season.

Prosch (1991) concluded that in South Africa Maurolicus muelleri spawns all year round with a peak in spring/summer. It has been demonstrated in
Japan (YUUKI, 1982) and in Norway (GJØSÆTER, 1981; DALPADADO; GJØSÆTER, 1987) that species of this genus present prolonged spawning in spring. In Tasmania, Young et al. (1987) reported that the spawning of $M$. muelleri begins in spring, extending into the summer, and Clarke (1982), in southeastern Australia, confirmed that this process begins in the winter and continues into spring. These results show that the different species of Maurolicus present great plasticity as regards the spawning season, which means different reproductive tactics in distinct physical and biological environmental conditions.

\section{Histology of the Ovaries}

Table 4 presents the characteristics of the oocytic developmental phases found for M. stehmanni. The analysis of the preparations of the ovaries resulting from cruises IV and $\mathrm{V}$ shows:

- Oocytes in phases II, III, IV and V, besides the postovulatory follicles (POs) and follicular atresia (Fig. 9) in the female gonads, macroscopically defined as mature females (stage C).

- No oocytes with pré-ovulatory hydration were found.

Table 4. Characteristics of the phases of oocytic development of M. stehmanni observed in this study.

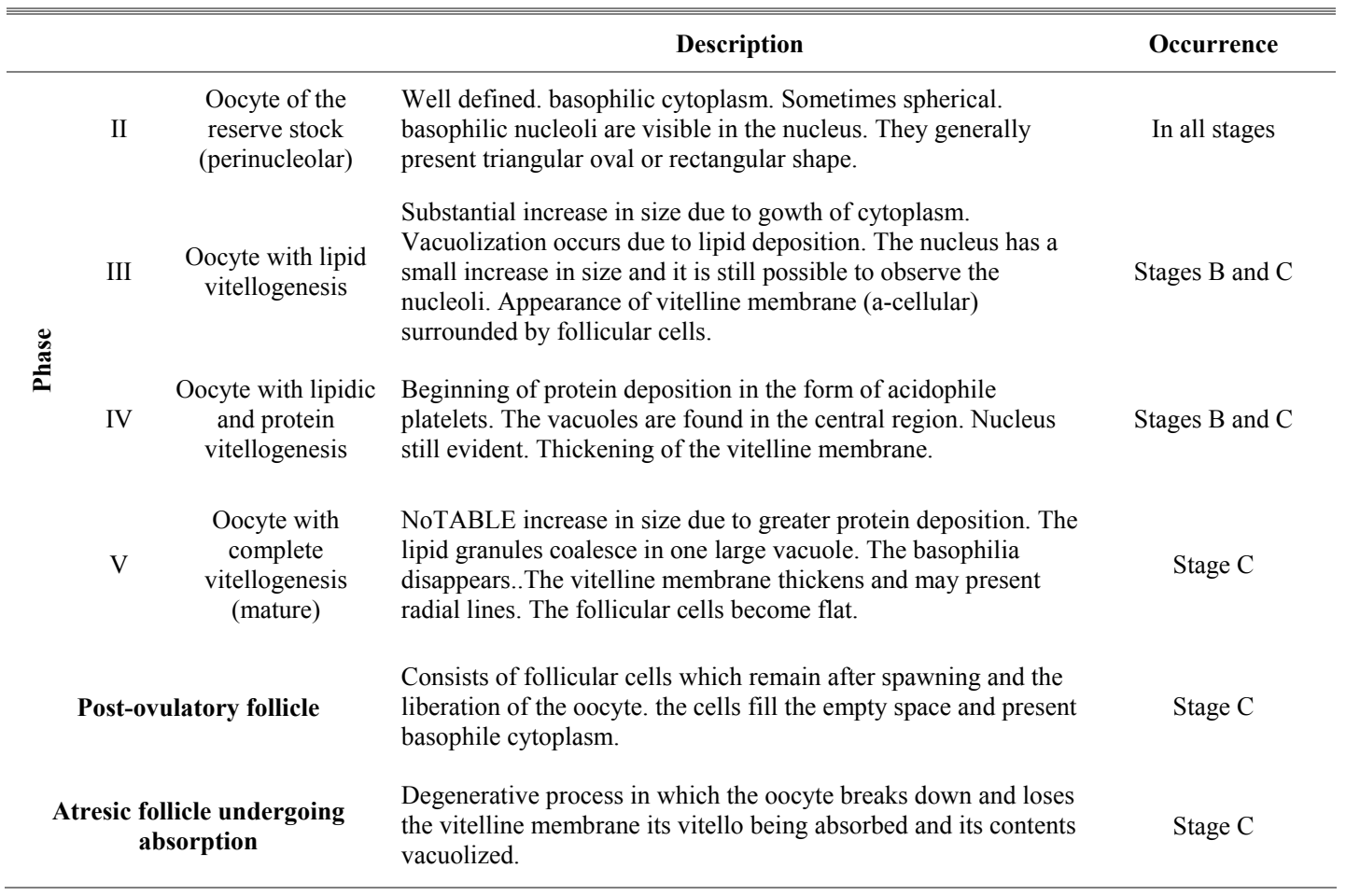


Figure 9 shows the presence of oocytes of types IV and $\mathrm{V}$, revealing a mature ovary, but the occurrence of ovulatory follicles (POs) indicating that spawning had already occurred has not been observed during the macroscopic analysis.

A
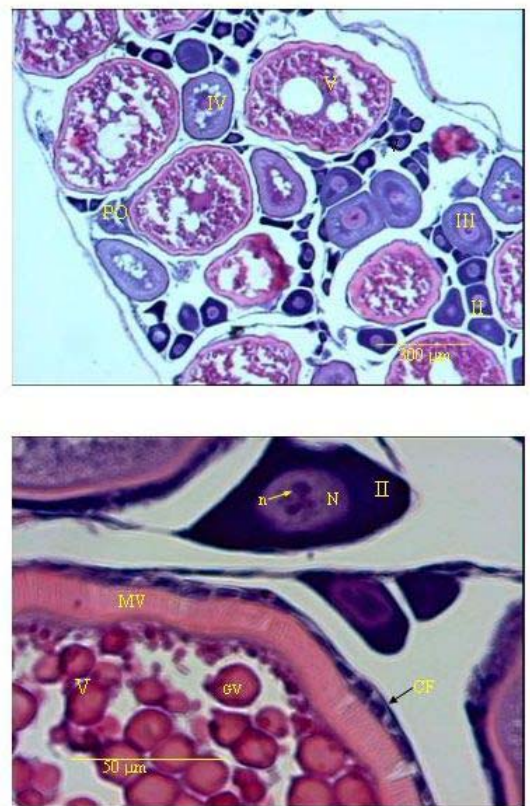

Fig. 9. Cross-sections of ovaries of specimens of Maurolicus stehmanni: A) Ovary in the mature stage (C) with oocytes in different phases of development (II, III, IV andV) and postovulatory follicle (PO). B) Oocyte in phase V, with complete vitellogenesis (V); VM - vitellinic membrane; $\mathrm{PG}$ - protein granule and $\mathrm{FC}$ - follicular cells and oocytes in phase II, of the reserve stock (II); $\mathrm{N}$ - nucleus and $\mathrm{n}$ - nucleole.

The absence of ovaries undergoing hydration showed that the females were not about to spawn, since hydration is a phenomenon characteristic of that moment, causing a substantial increase in the volume of the oocytes, which occurs a few hours only before the ejection into the external environment (CHAVES, 1989; VAZZOLER, 1996; DIAS et al., 1998).

As to the identification of the phases of maturation, the permanent preparations with sections of the gonads indicated that the macroscopic scale adopted was appropriate for the adult fish, but not for the immature ones with standard length smaller than $30 \mathrm{~cm}$, due to the very small size of the gonads which often presented weights of less than one mg.

It was detected that females with a standard length around $30 \mathrm{~cm}$, captured during the November 1997 cruise, and classified as being in the process of maturation (stage B), already presented oocytes in phases II, III and IV (Fig. 9e); however, females in the same condition, resulting from cruises I and II, were identified as immature (A), due to the very small size of the gonads, the filliform appearance of the ovaries and the presence of oocytes of small diameter. These data lead to the conclusion that a superestimation of the average size of the first maturation, which was of $32 \mathrm{~cm}$, may have occurred.

Dias et al. (1998) also reported differences between the macro and microscopic classifications of the ovaries in various teleosts species and called attention to the special care which should be taken regarding the macroscopic analysis of species with partial spawning, the liberation of the oocytes which may be macroscopically imperceptible, because their occurrence can only be accurately shown by the presence of post-ovulatory follicles (POs) (recent spawning) or of hydrated oocytes (imminent spawning), structures which are only visible in the histological preparations of ovaries.

Generally speaking, the classification of maturity stages undertaken by stereomicroscopy, underestimate the ovarian development. It was found that the relative size of $M$. stehmanni gonad, as also its irrigation and turgidity and the size and opacity of their oocytes, are not appropriate characteristics for the evaluation of the stages of gonadal maturity, thus demonstrating the absolute need for the analysis of cross-sections of the gonads prepared for their correct definition.

The presence, in one and the same ovary, of cells in the various phases of development and of postovulatory follicles (Fig. 9A) showed that the oocytic development of M. stehmanni is asynchronous. Melo and Armstrong (1991), studying the reproductive behavior of Maurolicus mulleri in South Africa, concluded that there must be multiple spawning. They arrived at this conclusion after a microscopic study of the gonads, in which they discovered the presence of post-ovulatory follicles, the existence of various kinds of modal values of frequencies of the oocytes diameters and that the number of juvenile oocytes was always greater than that of older oocytes. This is a characteristic of fishes which spawn frequently, after short intervals (PRABHU, 1956 apud MELO; ARMSTRONG, op. cit.), occurring commonly in species with prolonged spawning (HICKILING; RUTEMBERG, 1936, apud MELO; ARMSTRONG, op. cit.).

Hunter et al. (1985) show that fish which multiple spawning have gonads with oocytes distributed in many phases of development, their diameters varying continuously between oocytes without yolk and mature oocytes. West (1990) adds that the presence of various modes of oocytic development may indicate that more than one batch of oocytes will enter the process of maturation, although additional information is necessary to confirm multiple spawning. 
C

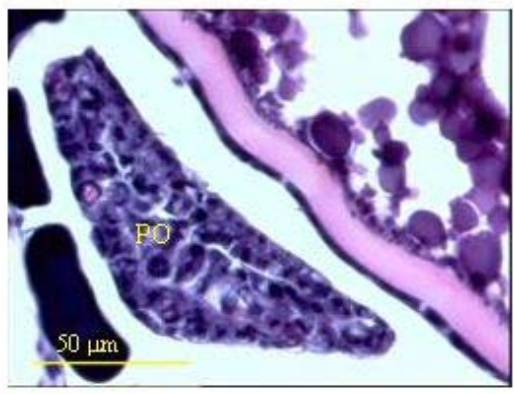

D

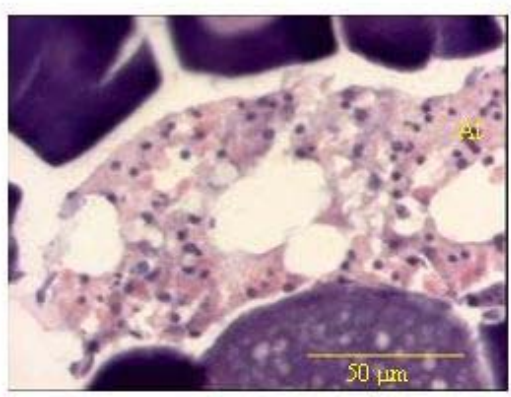

E

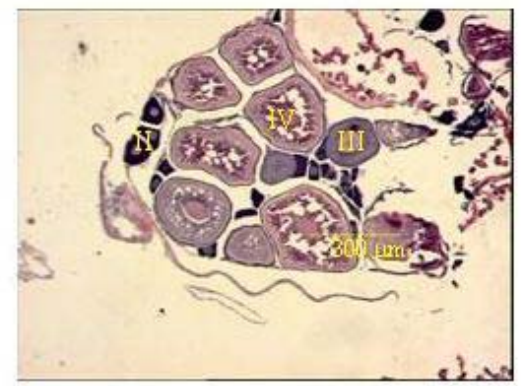

Fig. 9 (cont.). Cross-sections of ovaries from females of Maurolicus stehmanni: C) Postovulatory follicle (PO). D) Atresic follicle (At). E) Mature ovary (stage C) of a fish with standard length of $30 \mathrm{~mm}$, presenting oocytes in different phases of development (II, III e IV).

A fish with asynchronous oocytic development may present total spawning, and the nonmature oocytes would be absorbed (atresia) or the spawning would take place only after the complete development of all the oocytes in the more advanced phases of development. In this case, probably, the spawning would only be perceptible by the macroscopic evaluation of the ovaries, which would be empty, with a flacid appearance and a smaller weight, a fact not observed during this study.

Thus, the aspects mentioned above and the results obta ined show that M. stehmanni presents asynchronous oocytic development, spawns by phases, presents reproductive activity all the year round, over all the outer shelf and slope of the south-southeastern Brazilian region, and that the average length of the first gonadal maturation of the species being $32 \mathrm{~mm}$.

\section{AcKNowledgements}

This paper is part of Eduardo M. de Almeida MSc thesis at Instituto Oceanográfico - Universidade de São Paulo and was supported by the program focusing the Evaluation of the Potential of Living Resources of the Brazilian Exclusive Economic Zone (REVIZEE). 


\section{REFERENCES}

ANKEBRANDT, L. Food habits of Bait-Caught Skipjack tuna, Katsuwonus pelamis, from the southwestern atlantic ocean. Fish. Bull.., v. 83, n. 3, p. 379-393, 1985.

ALMEIDA, E. M. DE. Estrutura da população, crescimento e reprodução de Maurolicus stehmanni Parin \& Kobyliansky, 1993 (Teleostei: Sternoptychidae) na Zona Ecônomica Exclusiva do Sul e Sudeste do Brasil. 2001. 118 p. Dissertação de Mestrado, Universidade de São Paulo, Instituto Oceanográfico, São Paulo. Disponível em http://www.teses.usp.br/teses/disponiveis/21/21131/tde28092001-131903/. acesso em: 3 de mar. de 2004.

BELLUCCO, A; HARA, A.; ALMEIDA, M. DE A.; ROSSI-WONGTSCHOWSKI, C. L. D. B. Growth parameters estimates of Maurolicus stehmanni Parin \& Kobyliansky, 1996 (Teleostei: Sternoptychidae) From South and southeastern Brazilian waters. Braz. J. Oceanogr., v. 52, n. 3, p. 195-205, 2004.

BONECKER, A. C. T.; HUBOLD, G. Distribution and abundance of larval gonostomatidae fishes in the southwest Atlantic. Meeresforsch., v. 33 , n. 1, p. $38-$ 51,1990

CHAVES, P. DE T. C. Hidratação pré-ovulatória em peixes: Um caráter de origem marinha? Revta bras. Zool., v. 6 n. 3 , p. $463-472,1989$.

CLARKE, T. A . Distribution, growth, and reproduction of the lightfish Maurolicus muelleri (Sternoptychidae) off south-east Australia. CSIRO mar. . Labs Rept., v. 145 , p. $1-12,1982$.

DALPADADO, P.; GJØSÆTER, J. Observations on mesopelagic fish from the Red Sea. Mar. Biol., Mar Vermelho, v. 96, p. 173 - 183, 1987.

DIAS, J.F.; PERES-RIOS, E.; CHAVES, P. de T. C.; ROSSI-WONGTSCHOWSKI, C. L. D. B. Análise macroscópica dos ovários de teleosteos: Problemas de classificação e recomendações de procedimentos. Revta. bras. Biol., v. 58, n. 1, p. 55-69, 1998.

FIGUEIREDO, J. L.; SANTOS, A. P.; N. YAMAGUTI, N.; BERNARDES, R. A.; ROSSI-WONGTSCHOWSKI, C. L. D. B. Peixes da Zona Econômica Exclusiva da Região Sudeste-Sul do Brasil. Levantamento com rede de meia-água. São Paulo: Edusp, 2002, 248 p.

GJØSÆTER, J. Life history and ecology of Maurolicus muelleri (Gonostomatidae) in Norwegian waters. FiskDir. Skr. Ser. Havunders., v. 17, p. $109-131$, 1981.

GREIG, A. B. Determinação da distribuição e estimativa da abundância de Maurolicus muelleri (Gmelin, 1789); (teleostei: Sternoptychidae) por método hidroacústico na região sudeste-sul do Brasil, para a primavera de 1997. 2000. 104 p. Dissertação de Mestrado. Fundação Universidade do Rio Grande, Rio Grande, RS.

HAIMOVICI, M.; MARTINS, A. S.; FIGUEIREDO, J. L.; VIEIRA, P. C. Demersal bony fish of the outer shelf and upper slope of the southern Brazil subtropical convergence ecosystem. Mar. Ecol. Prog. Ser., v. 108, n. 1-2, p. 59-77, 1994.

HUNTER, J. R.; LO, N. C. H.; LEONG, R. J. H. Batch fecundity in multiple spawning fishes. NOAA Tech. Rept., EUA, v. 36, p. 67 - 76, 1985.
KING, M. Fisheries biology, assessment and management. Oxford: Fishing Book News, 1995, 146 p.

LONGHURST, A. R.; PAULY, D. 1987. Ecology of Tropical Oceans. London: Academic Press, 1987. 407p.

MADUREIRA, L.S.; ROSSI-WONGTSCHOWSKI, C. L. D. B. (Ed.). Prospecção de recursos pelágicos na Zona Econômica Exclusiva da Região Sudeste-Sul do Brasil: hidroacústica e biomassas. São Paulo: Instituto Oceanográfico, USP, 2005. 144 p. (Série Documentos Revizee - Score Sul).

MADUREIRA, L. S.; HABIAGA, R. P.; DUVOISIN, A.; ELISEIRE, D. J.; SOARES, C. F.; WEIGERT, S. C.; FERREIRA, C. S.; SALDO, P. A. Identificação de registrros acústicos do calamar argentino Illex argentinus (Castellanos, 1960) no talude da Região Sudeste-Sul do Brasil. São Paulo: Instituto Oceanográfico, USP. 2005. 32 p. (Série Documentos Revizee - Score Sul).

MELO, Y. C.; ARMSTRONG, M. J. Batch spawning behavior in lightfish Maurolicus muelleri. S. Afr. J. mar. Sci., v. 10, p. $125-130,1991$.

PARIN, N. V.; KOBYLIANSKY, S. G. Review of the genus Maurolicus (Sternoptychidae, Stomiiformes), with reestablishing validity of five species considered junior synonyms of $M$. muelleri and descriptions of nine new species. Trudy Inst. Okeanol., v. 128, p. $69-107$, 1993.

PROSCH, R. M. Reproductive biology and spawning of the myctophid Lampanyctodes hectoris and the sternoptychid Maurolicus muelleri in the southern Benguela ecosystem. S. Afr. J. Mar. Sci., v. 10, p. 241$252,1991$.

RASMUSSEN, O. I.; GISKE, J. Life-history parameters and vertical distribution of Maurolicus muelleri in Masfjorden in summer. Mar. Biol., v. 120, n. 4, p. 649-664, 1994.

RIBEIRO, M. R. Estudos sobre o desenvolvimento larval, abundância e distribuição de ovos e larvas de Maurolicus muelleri (Gmelin, 1789) (Teleostei: Sternoptychidae), e possíveis potencialidades ao largo da costa sudeste brasileira, compreedida entre $23^{\circ} \mathrm{S}$. (Cabo Frio-RJ) e $2^{\circ} \mathrm{S}$ (Cabo de Santa Marta Grande-SC). 1996. 160 p. Dissertação de mestrado, Instituto Oceanográfico, USP, São Paulo.

SALVANES, A. G. V.; STOCKLEY, B. M. Spatial variation of growth and gonadal developments of Maurolicus muelleri in the Norwegian Sea and in Norwegian fjord. Mar. Biol., v. 126, n. 2, p. $321-332,1996$.

STEARNS, S. C.; CRANDALL, R. E. Plasticity for age at sexual maturity: a life-history responses to unavoidable stress. In: POTTS, G. W.; WOOTTON, R. J. (Ed.). Fish reproduction: strategies and tactics. London: Academic Press, p. 13 - 33, 1984.

VAZZOLER, A. E. A. de M. Biologia da reprodução de peixes teleósteos: Teoria e Prática. Maringá: Eduem, 1996, 169 p.

WEISS, G.; HUBOLD, G.; BONECKER, A. C. T. Eggs and larvae of Maurolicus muelleri (Gmelin, 1789)(Teleostei, Sternoptychidae) in the southwest Atlantic. Meeresforschung, v. 32, p. 53 - 60, 1988.

WEST, G. Methods of Assessing Ovarian Development in fishes: a Review. Aust. J. Mar. Freshwater Res., Austrália, v. 41, p. 199 - 222. 1990. 
WOOTTON, R. J. Ecology of Teleotei Fishes. Londres: Chapman \& Hall. 1990, 404p.

YOUNG, J. W.; BLABER, S. J. M.; ROSE, R. Reproductive biology of three species of midwater fishes associated with the continental slope of Eastern Tasmania, Australia. Mar. Biol., Austrália, v. 95, p. 323 - 332, 1987.

YUUKI, Y. Age and growth of a sternoptychid fish Maurolicus muelleri in the south western waters of the Sea of Japan. Bull. japan. Soc. scient. Fish.., v. 50, n. 11, p. $1849-1854,1982$.
ZAR, J. H. Biostatistical analysis. New Jersey: Prentice Hall, 1996, 662 p.

ZAVALA-CAMIN, L. A. Hábitos alimentares e distribuição dos atuns e afins (Osteichthyes Teleostei) e suas relações ecologicas com outras espécies pelágicas das regiões sudeste e sul do Brasil.1981. 237 p Tese de Doutorado, Universidade de São Paulo, Instituto de Biociências, São Paulo.

(Manuscript received 20 March 2007; revised 05 May 2007; accepted 13 July 2007) 